\title{
PENGGUNAAN TEPUNG LIMBAH UDANG DENGAN PENGOLAHAN FILTRAT AIR ABU SEKAM, FERMENTASI EM-4 DAN KAPANG Trichoderma viride PADA RANSUM TERHADAP PERTUMBUHAN AYAM BROILER
}

\author{
(The Utilisation Shrimp by Product Meal Treated By Rice Husk Ash, Fermentation EM - 4 \\ and Trichoderma viride on Growth of Broiler)
}

\author{
Susi Susanti Kaban ${ }^{1}$, R.Edhy Mirwandhono ${ }^{2}$ dan Hasnudi $^{2}$ \\ 1. Mahasiswa Program Studi Peternakan Fakultas Pertanian Universitas SumateraUtara \\ 2. Staf Pengajar Program Studi Peternakan Fakultas Pertanian Universitas Sumatera Utara
}

\begin{abstract}
This research aimed to determine the of the effect of the utilisation of shrimp by product meal treated (TLU) by rice husk ash filtrate processing(FAAS), fermentation EM4 and Trichoderma viride (TV) in the diet on body weight gain, feed intake and feed conversion ratio of broiler chickens. The design used completely randomized design with 8 treatments and 3 replications, then analyzed by orthogonal contrasts . Treatment consists of POa (Commercial feed), POb (0\% TLU), P1 (5\% TLU FAAS), P2 (5\% TLU EM4), P3 (5\% TLU TV), P4 (10\% TLU FAAS), P5(10\% TLU EM4), P6(10\% TLU TV). The variables were measured consisted of feed consumption, body weight gain and feed conversion ratio. The results showed the average consumption ( $g /$ head / day ) for treatment P0a: 90.85, P0b: 80.22, P1: 80.63, P2: 80.02, P3: 81.13, P4: 77.15, P5: 78.54 and P6: 78.87. Mean body weight gain ( g/ bird / day ) P0a: 52.34, Pob: 42.09, P1: 41.52, P2: 41.61 , P3: 42.17, P4: 38.90, P5: 39,91 and P6: 40.33. Mean feed conversion P0a: 1.74, P0b: 1.91, P1:1.94, P2: 1.93, P3: 1.92, P4:1.99, P5: 1.97 and P6: 1.96. The conclusion of this study is the use of shrimp by product meal treated with rice husk ash filtrate treatment, fermentation EM4 and Trichoderma viride can increase body weight gain, feed in take and improve feed conversion at 5\% usage level in the ration, but showed lower performance than commercial feed.
\end{abstract}

Keywords : Growth, Shrimp by product, EM - 4, Trichoderma viride, Broiler.

\begin{abstract}
ABSTRAK
Penelitian ini bertujuan untuk mengetahui sejauh mana pengaruh penggunaan tepung limbah udang (TLU) dengan pengolahan filtrat air abu sekam (FAAS), fermentasi EM-4 dan kapang Trichoderma viride(TV) dalam ransum terhadap pertambahan bobot badan, konsumsi ransum dan konversi ransum ayam broiler. Rancangan yang dipakai adalah rancangan acak lengkap dengan 8 perlakuan dan 3 ulangan selanjutnya dianalisis dengan pembanding ortogonal kontras. Perlakuan terdiri P0a(Ransumkomersil), P0b(0\% TLU),P1(5\% TLU FAAS), P2(5\% TLU EM4), P3(5\% TLU TV),P4(10\% TLU FAAS), P5(10\% TLU EM4), P6(10\% TLU TV). Parameter yang diteliti adalah konsumsi ransum, pertambahan bobot badan dan konversi ransum. Hasil penelitian menunjukkan rataan konsumsi (g/ekor/hari) P0a:90,85, P0b:80,22, P1:80,63, P2:80,02, P3:81,13, $\mathrm{P} 4: 77,15$, P5:78,54 dan P6:78,87. Rataan pertambahan bobot badan (g/ekor/hari) P0a:52,34, P0b:42,09, P1:41,52, P2:41,61, P3:42,17, P4:38,90, P5:39,91 danP6:40,33. Rataan konversi ransum P0a:1,74, P0b:1,91, P1:1,94, P2:1,93, P3:1,92, P4:1,99, P5:1,97 dan P6:1,96. Kesimpulan dari penelitian ini adalah penggunaan tepung limbah udang dengan pengolahan filtrat air abu sekam, fermentasi EM4 dan kapang Trichoderma viride dapat meningkatkan pertambahan bobot badan, konsumsi ransum dan memperbaiki konversi ransum pada level pemakaian 5\% pada ransum, namun belum dapat mengimbangi penggunaan ransum komersil dalam meningkatkan pertambahan bobot badan, konsumsi ransum dan memperbaiki konversi ransum ayam broiler.
\end{abstract}

Kata kunci : Pertumbuhan, Tepung limbah udang, EM-4, Trichoderma viride, Ayam broiler. 


\section{PENDAHULUAN}

Tepung ikan merupakan bahan makanan sumber protein hewani yang sangat baik untuk ayam. Secara umum bahan ini mengandung protein yang tinggi antara $50-70 \%$. Tepung ikan adalah bahan baku pakan yang menyebabkan mahalnya harga ransum, karena tidak dapat dipenuhi dari produksi dalam negeri, sehingga lebih dari setengah, yaitu 200 ribu ton/tahun kebutuhan tepung ikan Indonesia disuplai dari impor. Oleh sebab itu untuk memenuhi kebutuhan peternak skala kecil dan menengah perlu bahan pakan alternatif sebagai pengganti tepung ikan ini. Salah satu bahan pakan alternatif adalah limbah udang (shrimp head waste).

Menurut Susana (1993), salah satu pilihan sumber protein adalah tepung limbah udang. Tepung limbah udang (TLU) merupakan limbah industri pengolahan udang yang terdiri dari kepala dan kulit udang. Proporsi kepala dan kulit udang diperkirakan antara 30$40 \%$ dari bobot udang segar. Faktor positif bagi tepung limbah udang adalah karena produk ini merupakan limbah, kesinambungan penyediaannya terjamin sehingga harganya akan cukup stabil dan kandungan nutrisinya pun bersaing dengan bahan baku lainnya. Industri pengolahan udang beku Indonesia berkembang sangat pesat pada beberapa tahun terakhir ini, sejalan dengan meningkatnya produksi udang. Indonesia termasuk negara pengekspor udang terbesar di dunia. Data Pokok Kelautan Dan Perikanan tahun 2010 menunjukkan produksi udang Indonesia sebesar 380.972 ton dan produksi ini meningkat sebesar $14 \%$ per tahun. Apabila udang segar ini diolah menjadi udang beku, maka sebesar 35\%-70\% dari bobot utuh akan menjadi limbah udang, kualitasnya bervariasi tergantung jenis udang dan proses pengolahannya.

Konsumsi ransum merupakan kegiatan masuknya sejumlah unsur nutrisi yang ada dalam ransum tersebut. Secara biologis ayam mengkonsumsi makanan untuk proses hidupnya. Kebutuhan energi untuk fungsi-fungsi tubuh dan memperlancar reaksi-reaksi asam amino dari tubuh. Hal ini menunjukkan ternak ayam dalam mengkonsumsi makanannya digunakan untuk kebutuhan ternak tersebut (Wahju, 1985).

Tingkat protein dan energi metabolisme yang berbeda berpengaruh terhadap konsumsi pakan, selisih kandungan energi metabolisme pada setiap pakan perlakuan tidak jauh berbeda, sehingga ayam pada tiap perlakuan cenderung mengkonsumsi pakan yang sama (Wahju, 1988).

Laju pertumbuhan seekor ternak dikendalikan oleh banyaknya konsumsi ransum dan energi yang diperoleh. Energi merupakan perintis pada produksi ternak dan hal tersebut 
terjadi secara alami. Variasi energi yang disuplai pada ternak akan digambarkan pada laju pertumbuhannya (Donald et al., 1995).

Pertambahan berat badan kerap kali digunakan sebagai pegangan berproduksi bagi peternak dan para ahli. Akan tetapi, perlu diketahui bahwa ada bibit ayam yang memang pertambahan berat badannya hebat, tetapi hebat pula makanannya. Padahal biaya untuk ransum adalah yang terbesar bagi suatu peternakan ayam. Oleh karena itu, pertambahan berat badan haruslah pula dikaitkan dengan ransumnya (Rasyaf, 1993).

Rasyaf (1997) menjelaskan bahwa, konversi pakan adalah jumlah ransum yang dikonsumsi seekor ayam dalam waktu tertentu untuk membentuk daging atau berat badan. Faktor yang mempengaruhi tingkat konversi pakan antara lain strain, kualitas pakan, keadaan kandang dan jenis kelamin.

Semakin baik mutu ransum, semakin kecil pula konversi ransumnya. Baik tidaknya mutu ransum ditentukan oleh seimbang tidaknya zat-zat gizi dalam ransum itu diperlukan oleh tubuh ayam. Ransum yang kekurangan salah satu unsur gizi akan mengakibatkan ayam akan memakan ransumnya secara berlebihan untuk mencukupi kekurangan zat yang diperlukan oleh tubuhnya (Sarwono, 1996).

Kandungan nutrisi tepung limbah udang dengan pengolahan filtrat air abu sekam yaitu protein kasar 39,02 \%, energi metabolisme 1646,00 \%, serat kasar 13,31\% dan lemak kasar 1,20\%. Kandungan nutrisi tepung limbah udang fermentasi EM-4 yaitu : protein kasar $42,00 \%$, energi metabolisme $2384 \%$, serat kasar 10,50 \% dan lemak kasar 1,25\%. Serta kandungan nutrisi tepung limbah udang fermentasi Trichoderma viride yaitu : protein kasar 46,12 \%, energi metabolisme $2610 \%$, serat kasar 9,48 \% dan lemak kasar 2,30 \% (Loka Penelitian Kambing Potong Sei Putih, 2013).

Adapun tujuan penelitian untuk mengetahui sejauh mana pengaruh penggunaan tepung limbah udang dengan pengolahan filtrat air abu sekam, fermentasi EM-4 dan kapang Trichoderma viride dalam ransum terhadap pertambahan bobot badan, konsumsi ransum dan konversi ransum ayam broiler.

\section{BAHAN DAN METODE PENELITIAN}

\section{Tempat dan Waktu Penelitian}

Penelitian telah dilaksanakan di Laboratorium Biologi Ternak Jln. Prof. Dr. A. Sofyan No.3 Program Studi Peternakan Fakultas Pertanian Universitas Sumatera Utara. Penelitian ini telah dilaksanakan selama 2 bulan yaitu bulan November 2013 sampai bulan Januari 2014. 


\section{Bahan dan Alat Penelitian}

Bahan yang digunakan yaitu Day old chick (DOC) sebanyak 120 ekor strain Cobb LH 500. Bahan penyusun ransum terdiri atas tepung jagung, dedak padi, bungkil kedelai, tepung ikan, tepung limbah udang dengan pengolahan filtrat air abu sekam, tepung limbah udang dengan fermentasi EM-4, tepung limbah udang dengan fermentasi Trichoderma viride, minyak nabati, dan top mix. Air minum untuk memenuhi kebutuhan air dalam tubuh diberikan secara ad libitum. Air gula untuk mengurangi stress dari kelelahan transportasi. Rodalon sebagai desinfektan kandang dan peralatan baik tempat pakan maupun tempat minum. Vaksin ND 5 Ma Clone ${ }^{\circledR}$, IBD® dan ND Lasota ${ }^{\circledR}$ untuk memberikan kekebalan tubuh broiler. Formalin $40 \%$ untuk fumigasi kandang. Vitamin seperti vitachick® sebagai suplemen tambahan.

Adapun alat yang digunakan yaitu kandang baterai berukuran $100 \mathrm{~cm}$ x $100 \mathrm{~cm} \mathrm{x}$ $50 \mathrm{~cm}$, jumlah kandang sebanyak 24 unit dan tiap unit di isi 5 ekor DOC, peralatan kandang terdiri dari 24 unit tempat minum dan 24 unit tempat pakan, timbangan salter dengan kapasitas $5 \mathrm{~kg}$ dengan kesetaraan $1 \mathrm{~g}$ untuk menimbang pertambahan bobot badan ayam, alat penerangan dan pemanas berupa lampu pijar 40 watt sebanyak 24 buah, Thermometer, alat pembersih kandang, pisau, plastik, ember, alat tulis, buku data dan kalkulator. Terpal dengan ukuran 3 x 6 sebanyak 4 buah sebagai penutup dinding ruangan.

\section{Metode Penelitian}

Adapun rancangan penelitian yang digunakan adalah rancangan acak lengkap (RAL) yang terdiri dari 8 perlakuan dan 3 ulangan dan setiap ulangan terdiri dari 5 ekor broiler. Perlakuan pada penelitian yaitu :

$\mathrm{P}_{0 \mathrm{a}}=$ Pakan komersil Charoen pokphand

$\mathrm{P}_{0 \mathrm{~b}}=$ Ransum formulasi dengan tepung ikan $10 \%$ dan tanpa TLU

$\mathrm{P}_{1}=$ Ransum formulasi dengan tepung ikan $5 \%$ dan $5 \%$ TLU FAAS

$\mathrm{P}_{2}=$ Ransum formulasi dengan tepung ikan $5 \%$ dan $5 \%$ TLU fermentasi EM - 4

$\mathrm{P}_{3}=$ Ransum formulasi dengan tepung ikan 5\% dan TLU fermentasi kapang Trichoderma viride $5 \%$

$\mathrm{P}_{4}=$ Ransum formulasi dengan $10 \%$ TLU FAAS

$\mathrm{P}_{5}=$ Ransum formulasi dengan $10 \%$ TLU fermentasi EM - 4

$\mathrm{P}_{6}=$ Ransum formulasi dengan $10 \%$ TLU fermentasi Trichoderma viride

Kandungan nutrisi ransum yang digunakan untuk penelitian pada Tabel 1 dan 2 . 
Tabel 1. Susunan Ransum Starter

\begin{tabular}{lcrrrrrrrr}
\hline Bahan Pakan & \multicolumn{8}{c}{ Susunan Ransum Perlakuan (\%) } \\
\cline { 2 - 10 } & $\mathbf{P}_{\mathbf{0 a}}$ & \multicolumn{1}{c}{$\mathbf{P}_{\mathbf{0 b}}$} & \multicolumn{1}{c}{$\mathbf{P}_{\mathbf{1}}$} & \multicolumn{1}{c}{$\mathbf{P}_{\mathbf{2}}$} & \multicolumn{1}{c}{$\mathbf{P}_{\mathbf{3}}$} & $\mathbf{P}_{\mathbf{4}}$ & $\mathbf{P}_{\mathbf{5}}$ & $\mathbf{P}_{\mathbf{6}}$ \\
\hline T.jagung & $\mathrm{K}$ & 46,5 & 49,9 & 50.0 & 50,0 & 49,8 & 50,0 & 50,5 \\
B.kedelai & $\mathrm{O}$ & 24,0 & 26,0 & 26,0 & 24,7 & 28,0 & 26,3 & 25,9 \\
Dedak & $\mathrm{M}$ & 15,0 & 11,0 & 11,0 & 12,8 & 9,4 & 11,0 & 11,0 \\
T.ikan & $\mathrm{E}$ & 10,0 & 5,0 & 5,0 & 5,0 & 0 & 0 & 0 \\
T.limbah udang FAAS & $\mathrm{R}$ & 0 & 5,0 & 0 & 0 & 10,0 & 0 & 0 \\
T.limbah udang EM-4 & $\mathrm{S}$ & 0 & 0 & 5,0 & 0 & 0 & 10,0 & 0 \\
T.limbah udang TCD & $\mathrm{I}$ & 0 & 0 & 0 & 5,0 & 0 & 0 & 10,0 \\
Top mix & $\mathrm{L}$ & 0,5 & 0,2 & 0,3 & 0,2 & 0,1 & 0,2 & 0,1 \\
M.nabati & & 3,5 & 2,9 & 2,7 & 2,3 & 2,7 & 2,5 & 2,5 \\
\hline Jumlah & & 100 & 100 & 100 & 100 & 100 & 100 & 100 \\
\hline Protein (\%) & & 22,01 & 22,00 & 22,16 & 22,02 & 22,01 & 22,03 & 22,04 \\
Lemak (\%) & & 4,62 & 3,68 & 3,69 & 3,84 & 3,28 & 3,42 & 3,54 \\
Serat Kasar (\%) & & 3,57 & 3,95 & 3,81 & 3,91 & 4,46 & 4,24 & 4,13 \\
Kalsium (\%) & & 0,72 & 1,11 & 0,84 & 1,07 & 1,58 & 1,02 & 1,51 \\
Fosfor (\%) & & 0,82 & 0,69 & 0,69 & 0,68 & 0,58 & 0,59 & 0,54 \\
ME (kkal/kg) & & 3009,10 & 3005,61 & 3028,27 & 3002,28 & 2961,57 & 3008,60 & 3037,70 \\
\hline
\end{tabular}

Tabel 2. Susunan Ransum Finisher

\begin{tabular}{|c|c|c|c|c|c|c|c|c|}
\hline \multirow[t]{2}{*}{ Bahan Pakan } & \multicolumn{8}{|c|}{ Susunan Ransum Perlakuan (\%) } \\
\hline & $\mathbf{P}_{0 \mathrm{a}}$ & $\mathbf{P}_{\mathbf{0 b}}$ & $\mathbf{P}_{1}$ & $\mathbf{P}_{2}$ & $\mathbf{P}_{3}$ & $\mathbf{P}_{4}$ & $\mathbf{P}_{5}$ & $\mathbf{P}_{6}$ \\
\hline T.jagung & $\mathrm{K}$ & 52,5 & 55,3 & 55,0 & 53,8 & 53,0 & 53,5 & 53,4 \\
\hline B.kedelai & $\mathrm{O}$ & 18,5 & 20,6 & 22,0 & 20,0 & 22,7 & 22,0 & 22,0 \\
\hline Dedak & $\mathrm{M}$ & 15,0 & 11,0 & 10,0 & 13,5 & 11,0 & 11,0 & 12,0 \\
\hline T.ikan & $\mathrm{E}$ & 10,0 & 5,0 & 5,0 & 5,0 & 0 & 0 & 0 \\
\hline T.limbah udang FAAS & $\mathrm{R}$ & 0 & 5,0 & 0 & 0 & 10,0 & 0 & 0 \\
\hline T.limbah udang EM-4 & $\mathrm{S}$ & 0 & 0 & 5,0 & 0 & 0 & 10,0 & 0 \\
\hline T.limbah udang TCD & I & 0 & 0 & 0 & 5,0 & 0 & 0 & 10,0 \\
\hline Top mix & $\mathrm{L}$ & 0,5 & 0,2 & 0,3 & 0,2 & 0,1 & 0,2 & 0,1 \\
\hline M.nabati & & 3,5 & 2,9 & 2,7 & 2,5 & 3,2 & 3,3 & 2,5 \\
\hline Jumlah & & 100 & 100 & 100 & 100 & 100 & 100 & 100 \\
\hline Protein (\%) & & 20,05 & 20,04 & 20,66 & 20,32 & 20,11 & 20,35 & 20,66 \\
\hline Lemak (\%) & & 4,80 & 3,84 & 3,75 & 4,00 & 3,49 & 3,51 & 3,70 \\
\hline Serat Kasar (\%) & & 3,46 & 3,83 & 3,66 & 3,85 & 4,43 & 4,13 & 4,11 \\
\hline Kalsium (\%) & & 0,65 & 1,09 & 0,83 & 1,06 & 1,56 & 1,01 & 1,50 \\
\hline Fosfor (\%) & & 0,80 & 0,67 & 0,66 & 0,67 & 0,58 & 0,58 & 0,54 \\
\hline ME (kkal/kg) & & 3069,02 & 3047,95 & 3075,79 & 3038,69 & 3004,46 & 3085,83 & 3052,11 \\
\hline
\end{tabular}

Menurut Hanafiah (2003) linear untuk rancangan acak lengkap (RAL) adalah :

$$
\mathbf{Y i j}=\boldsymbol{\mu}+\boldsymbol{\sigma} \mathbf{i}+\boldsymbol{\epsilon} \mathbf{i j}
$$

Keterangan :

$\mathrm{I} \quad=1,2,3, \ldots . \mathrm{i}=$ perlakuan

$\mathrm{J}=1,2,3, \mathrm{j}=$ ulangan

Yij = nilai pengamatan pada perlakuan $\mathrm{k}-\mathrm{i}$, ulangan $\mathrm{ke}-\mathrm{j}$

$\mu \quad=$ nilai tengah umum

бi = pengaruh perlakuan ke-i

$€ \mathrm{ij}=$ efek $\mathrm{j}$ galat pada perlakuan $\mathrm{k}-\mathrm{i}$, ulangan ke- $\mathrm{j}$ 


\section{Analisis Data}

Data yang diperoleh selama penelitian dari setiap perlakuan dianalisis dengan perbandingan linier ortogonal kontras sehingga diperoleh informasi perlakuan yang terbaik. Dari 8 perlakuan dapat disusun 7 pembandingan linier ortogonal kontras sebagai berikut : P0a vs P0bP1P2P3P4P5P6, P0b vs P1P2P3P4P5P6, P1P2P3 vs P4P5P6, P1 vs P2P3, P2 vs P3, P4 vs P5P6 dan P5 vs P6.

\section{Parameter Penelitian}

Konsumsi Ransum (g)

Konsumsi ransum dihitung berdasarkan selisih antara jumlah ransum yang diberikan dikurangi dengan jumlah ransum yang sisa (Sodiq dan Abidin, 2002).

Konsumsi ransum $=$ Ransum yang diberikan - Ransum sisa

Pertambahan Bobot Badan (g)

Pertambahan bobot badan yang diperoleh dengan menghitung selisih bobot badan akhir dengan selisih bobot badan awal (Sodiq dan Abidin, 2002). Penimbangan dilakukan setiap seminggu sekali.

Pertambahan bobot badan $=\frac{\text { bobot badan akhir }- \text { bobot nadan awal }}{\text { lama pemeliharaan }}$

Konversi Ransum (FCR)

Konversi ransum merupakan ratio antara konsumsi ransum dengan pertambahan bobot badan (Rasyaf, 1997).

$\mathrm{FCR}=\frac{\text { banyaknya ransum yang dihabiskan }}{\text { berat badan yang di dapat/dicapai }}$

Proses pembuatan TLU dengan pengolahan filtrat air abu sekam diawali dengan menggumpulkan dan membersihkan limbah udang dengan air bersih, kemudian limbah udang direndam dengan filtrat air abu sekam selama 48 jam, setelah itu limbah udang ditiriskan dan dikukus selama 45 menit. Kemudian limbah udang dikeringkan dengan oven lalu digiling. Proses pembuatan TLU fermentasi EM - 4 diawali dengan menggumpulkan dan membersihkan limbah udang dengan air bersih, kemudian limbah udang dikeringkan dengan oven lalu digiling. Tepung limbah udang difermentasi dengan EM - 4 dengan dosis 20 $\mathrm{mL} / 100 \mathrm{~g}$ substrat dengan lama fermentasi 11 hari, setelah 11 hari TLU dikeringkan. Proses pembuatan TLU fermentasi Trichoderma viride diawali dengan menggumpulkan dan membersihkan limbah udang dengan air bersih, kemudian limbah udang dikeringkan dengan 
oven lalu digiling. Tepung limbah udang difermentasi dengan kapang Trichoderma viride selama 48 jam kemudian TLU dikeringkan.

\section{HASIL DAN PEMBAHASAN}

Rataan dari parameter yaitu : konsumsi ransum, pertambahan bobot badan dan konversi ransum dapat dilihat dari Tabel 3.

Tabel 3. Rekapitulasi hasil penelitian

\begin{tabular}{lccc}
\hline Perlakuan & $\begin{array}{c}\text { Konsumsi Ransum } \\
\text { (g/ekor/hari) }\end{array}$ & $\begin{array}{c}\text { Pertambahan Bobot } \\
\text { Badan } \\
\text { (g/ekor/hari) }\end{array}$ & Konversi Ransum \\
\hline P0a & $90,85 \pm 0,20$ & $52,34 \pm 1,06$ & $1,74 \pm 0,03$ \\
P0b & $80,22 \pm 1,01$ & $42,09 \pm 1,07$ & $1,91 \pm 0,05$ \\
P1 & $80,63 \pm 1,01$ & $41,52 \pm 0,73$ & $1,94 \pm 0,01$ \\
P2 & $80,02 \pm 1,18$ & $41,61 \pm 1,66$ & $1,93 \pm 0,09$ \\
P3 & $81,13 \pm 0,70$ & $42,17 \pm 1,08$ & $1,92 \pm 0,04$ \\
P4 & $77,15 \pm 0,99$ & $38,90 \pm 1,68$ & $1,99 \pm 0,09$ \\
P5 & $78,54 \pm 2,15$ & $39,91 \pm 1,47$ & $1,97 \pm 0,02$ \\
P6 & $78,87 \pm 0,76$ & $40,33 \pm 0,49$ & $1,96 \pm 0,02$ \\
\hline
\end{tabular}

Hasil penelitian didapat perbandingan setiap perlakuan dengan menggunakan uji ortogonal kontras konsumsi ransum, pertambahan bobot badan dan konversi ransum pada Tabel 4.

Tabel 4. Ortogonal kontras.

\begin{tabular}{lrrrrr}
\hline \multicolumn{1}{c}{ SV } & \multicolumn{1}{c}{ Fhit } & \multicolumn{3}{c}{ Ftabe } \\
& \multicolumn{1}{c}{$\begin{array}{c}\text { Konsumsi } \\
\text { ransum }\end{array}$} & $\begin{array}{c}\text { Pertambahan } \\
\text { bobot badan }\end{array}$ & $\begin{array}{c}\text { Konversi } \\
\text { ransum }\end{array}$ & 0,05 & 0,01 \\
& $41,92^{* *}$ & $35,3320^{* *}$ & $6,7478^{* *}$ & 2,66 & 4,03 \\
\hline Perlakuan & $266,0817^{* *}$ & $228,8103^{* *}$ & $41,9083^{* *}$ & 4,49 & 8,53 \\
P0avsP0bP1P2P3P4P5P6 & $1,4030^{\text {tn }}$ & $3,1444^{\text {tn }}$ & $1,8345^{\text {tn }}$ & 4,49 & 8,53 \\
P0b vs P1P2P3P4P5P6 & $20,5328^{* *}$ & $12,6850^{* *}$ & $2,8169^{\text {tn }}$ & 4,49 & 8,53 \\
P1P2P3 vs P4P5P6 & $0,0045^{\text {tn }}$ & $0,1849^{\text {tn }}$ & $0,1667^{\text {tn }}$ & 4,49 & 8,53 \\
P1 vs P2P3 & $1,4472^{\text {tn }}$ & $0,3186^{\text {tn }}$ & $0,0062^{\text {tn }}$ & 4,49 & 8,53 \\
P2 vs P3 & $3,8179^{\text {tn }}$ & $2,0033^{\text {tn }}$ & $0,4033^{\text {tn }}$ & 4,49 & 8,53 \\
P4 vs P5P6 & $0,1261^{\text {tn }}$ & $0,1771^{\text {tn }}$ & $0,0988^{\text {tn }}$ & 4,49 & 8,53 \\
P5 vs P6 & & & & & \\
\hline
\end{tabular}

\section{Konsumsi Ransum}

Rataan konsumsi ransum tertinggi selama penelitian yaitu P0a : 90,85 dan rataan konsumsi terendah yaitu P4 : 77,15. Konsumsi ransum dihitung berdasarkan selisih antara jumlah ransum yang diberikan dikurangi dengan jumlah ransum yang sisa. Dari hasil 
penelitian dapat dilihat bahwa konsumsi ransum broiler pada setiap perlakuan semakin menurun pada peningkatan penggunaan tepung limbah udang pada ransum menjadikan konsumsi ransumnya semakin menurun. Konsumsi ransum tertinggi terdapat pada P0a (ransum dengan perlakuan pakan komersil) dan konsumsi pakan terendah terdapat pada P4 (ransum dengan perlakuan 10\% TLU FAAS). Hal ini dapat disebabkan oleh tingginya kandungan serat kasar pada tepung limbah udang dalam bentuk kitin menyebabkan ransum bersifat amba (volumenous), sehingga akan menurunkan konsumsi ransum dan pertambahan bobot badan. Tepung limbah udang yang bersifat amba (volumenous) menyebabkan ayam broiler cepat merasa kenyang dan tidak mau makan lagi, sehingga menurunkan konsumsi ransum. Namun sebenarnya ayam broiler masih lapar secara fisiologis yang artinya ayam broiler masih kekurangan nutrisi untuk memenuhi kebutuhan nutrisi dan metabolismenya. Hal ini sesuai dengan pernyataan Razdan dan Pettterson (1994) yang menyatakan bahwa kadar kitin diatas 5\% dalam ransum ayam broiler akan menekan konsumsi ransum dan pertumbuhan ayam broiler.

Pada perlakuan P0b dibandingkan dengan P1, P2, P3, P4, P5 dan P6 menunjukkan pengaruh yang tidak berbeda nyata terhadap konsumsi ransum ayam broiler selama 5 minggu. Peningkatan pemakaian tepung limbah udang dengan pengolahan FAAS ,fermentasi EM4 dan fermentasi kapang Trchoderma viride sampai pada tingkat 100\% sebagai pengganti tepung ikan ternyata tidak banyak mempengaruhi konsumsi ransum selama penelitian. Hal ini sesuai dengan pernyataan Wahyuni dan Budiastuti (1991); Reddy et al (1996); Rosenfield et al (1997) dan Ramadhan (2005), bahwa konsumsi ransum tidak berbeda nyata pada ayam broiler yang diberi tepung limbah udang olahan dalam ransumnya. Begitu juga Filawati (2003) melaporkan bahwa pemanfaatan tepung limbah udang olahan dengan cara fisikokimia pada ransum ayam petelur memberikan pengaruh tidak berbeda nyata terhadap konsumsi.

Tingkat konsumsi ransum juga dipengaruhi oleh kandungan nutrisi dan faktor lainnya seperti pengolahan dan palatabilitas yang merupakan sifat performans yang dicerminkan oleh organoleptik seperti kenampakan, bau, rasa dan tekstur. Selain itu konsumsi ransum juga dipengaruhi oleh beberapa faktor diantaranya adalah bentuk fisik ransum, bobot badan, jenis kelamin, temperatur lingkungan, keseimbangan hormonal dan fase pertumbuhan. Hal ini sesuai dengan pernyataan Piliang (2000) yang menyatakan bahwa konsumsi ransum juga dipengaruhi oleh beberapa faktor diantaranya palatabilitas ransum, bentuk fisik ransum, bobot badan, jenis kelamin, temperatur lingkungan, keseimbangan hormonal dan fase pertumbuhan. 


\section{Pertambahan Bobot Badan}

Rataan pertambahan bobot badan tertinggi terdapat pada perlakuan P0a (ransum dengan perlakuan pakan komersil), sedangkan pertambahan bobot badan terendah terdapat pada perlakuan P4(ransum dengan perlakuan 0\% tepung ikan dan 10\% TLU FAAS). Pada perlakuan P0b dibandingkan dengan perlakuan P1, P2, P3, P4, P5 dan P6 yang tidak berbeda nyata terhadap pertambahan bobot badan disebabkan oleh konsumsi ransum yang sama pada setiap perlakuan, sehingga dihasilkan pertambahan bobot badan yang sama pula pada akhir penelitian. Hal ini erat kaitannya dengan konsumsi, dimana konsumsi berbanding lurus dengan pertambahan bobot badan. Hal ini sesuai dengan pendapat Kartadisastra (1997) yang menyatakan bahwa bobot badan tubuh ternak senantiasa berbanding lurus dengan tingkat konsumsi pakan, makin tinggi bobot tubuhnya makin tinggi pula konsumsi pakan. Selain itu, dari uji analisa pakan tepung limbah udang yang diolah dengan FAAS, fermentasi EM4 dan fermentasi kapang Trichoderma viride dapat meningkatkan kandungan nutrisi tepung limbah udang tersebut, seperti meningkatkan kandungan proteinnya sehingga mempengaruhi pertumbuhan ternak ayam broiler tersebut. Hal ini sesuai dengan pernyataan Wahju (1998) yang menyatakan bahwa faktor-faktor yang mempengaruhi pertumbuhan adalah bangsa, jenis kelamin, energi metabolisme, kandungan protein dan suhu lingkungan.

Adanya peningkatan kualitas dari tepung limbah udang olahan akan berpengaruh dalam ransum, sehingga dapat digunakan lebih banyak sebagai pengganti protein tepung ikan dalam ransum ayam broiler. Perbedaan yang nyata antara ransum perlakuan P1, P2, P3 dengan perlakuan P4, P5, P6 disebabkan oleh semakin menurunnya konsumsi ransum pada P4, P5, P6 akibat penggunaan tepung limbah udang yang tinggi, walaupun secara statistik tidak berbeda, namun penurunan tersebut sudah berpengaruh terhadap keseimbangan zat-zat makanan ransum tersebut, sehingga menurunkan pertumbuhan bobot badan ayam broiler.

\section{Konversi ransum}

Rataan konversi ransum terdapat pada perlakuan P0a (ransum dengan perlakuan pakan komersil), sedangkan konversi ransum tertinggi terdapat pada perlakuan $\mathrm{P} 4$ (ransum dengan perlakuan $0 \%$ tepung ikan dan 10\% TLU FAAS). Konversi ransum merupakan perbandingan antara jumlah ransum yang dikonsumsi dengan pertambahan berat badan ayam. Angka konversi ransum menunjukkan suatu prestasi penggunaan ransum seekor ayam, dimana semakin rendah nilai konversi ransum semakin efisien penggunaan ransum tersebut oleh ternak ayam. 
Pada perlakuan P0bdibandingkan dengan perlakuan P1, P2, P3, P4, P5 dan P6 memperlihatkan perbedaan yang tidak berbeda nyata terhadap konversi ransum ayam broiler. Hal ini disebabkan konsumsi ransum dan pertambahan bobot badan sampai taraf pemakaian $10 \%$ tidak menunjukkan perbedaan yang nyata, sehingga perbandingan antara konsumsi ransum dan pertambahan bobot badan menunjukkan hasil yang tidak berbeda pula. Hal ini sesuai dengan pernyataan Rasyaf (1997) yang menyatakan konversi ransum merupakan suatu nilai perbandingan antara jumlah ransum yang dikonsumsi dengan pertambahan bobot badan ayam broiler, dan angka konversi ransum memperlihatkan suatu prestasi penggunaan ransum oleh seekor ayam broiler. Semakin rendah nilai konversi ransum semakin efisien penggunaan ransum tersebut oleh ayam broiler.

Konversi ransum yang menggunakan tepung limbah udang olahan sampai $10 \%$ dalam ransum, yaitu P4, P5, P6 menghasilkan angka konversi yang tidak berbeda nyata dengan P1, P2, P3. Hal ini disebabkan perlakuan P4, P5, P6 menunjukkan penurunan bobot badan yang sejalan dengan penurunan pada konsumsi ransumnya, sehingga diperoleh konversi ransum sebanding dengan perlakuan lain. Karena konversi ransum adalah perbandingan antara konsumsi dengan pertambahan bobot badan. Semakin baik mutu ransum, semakin kecil pula konversi ransumnya. Baik tidaknya mutu ransum ditentukan oleh seimbang tidaknya zat-zat gizi dalam ransum itu diperlukan oleh tubuh ayam. Ransum yang kekurangan salah satu unsur gizi akan mengakibatkan ayam akan memakan ransumnya secara berlebihan untuk mencukupi kekurangan zat yang diperlukan oleh tubuhnya (Sarwono, 1996).

\section{KESIMPULAN}

Penggunaan tepung limbah udang dengan pengolahan filtrat air abu sekam, fermentasi EM4 dan kapang Tricoderma viride dapat meningkatkan pertambahan bobot badan, konsumsi ransum dan memperbaiki konversi ransum pada level pemakaian 5\% pada ransum, namun belum dapat mengimbangi penggunaan ransum komersil dalam meningkatkan pertambahan bobot badan, konsumsi ransum dan memperbaiki konversi ransum ayam broiler.

\section{DAFTAR PUSTAKA}

BPS. 2010. Statistik Perdagangan Luar Negeri Indonesia. Eksport. Badan Pusat Statistik, Jakarta. 
Donald, Mc, P., Edward, A. R., Green Halg, J. F. O and Morgan, A. C. 1995. Animal Nutrition Fifth Editing, Ohn Wiley \& Sons Inc, New York. Feed Procedings of The MASP Ann. Conf. Kuala Penggaru PP. 56-61.

Filawati.2003. Pengolahan Limbah Udang Secara Fisikokimia dan Pengaruh Pemanfaatannya dalam Ransum Terhadap Penampilan Produksi Ayam Petelur. Thesis Pascasarjana Universitas Andalas, Padang.

Hanafiah, K.A. 2003. Rancangan Percobaan. Fakultas Pertanian, Universitas Sriwijaya, Palembang.

Laboratorium Loka Penelitian Kambing Potong, Sei Putih. 2013.

Piliang W. G., 2000. Fisologi Nutrisi. Volume I. Institut Pertanian, Bogor.

Ramadhan, S. 2005. Pengaruh pemakaian limbah udang yang difermentasi dengan Effective Microorganism 4 (EM4) terhadap performans ayam broiler. Skripsi. Fakultas Peternakan, Universitas Andalas, Padang.

Rasyaf, M. 1997. Pengelolaan Peternakan Unggas Pedaging. Kanisius. Yogyakarta.

Razdan, A and D. Petterson. 1994. Effect of chitin and chitosan on nutrient digestibility and plasmalipid concentrations in broiler chickens. Brit. J. Nut. 72: 277-288.

Reddy, V.R., V.R. Reddy and S. Quddratullah. 1996. Squilla: A novel animal protein, can it be used as a complete subtitute for fish in poultry ration. Feed Int. 17:1820.Replacement of Fish Meal With Chemically Preserved Shrimp Head In The Diets of African Catfish, Clarias Gariepinus. J. Food Agri. And Environment.

Rosenfield, D.J., A.G. Gernat, J.D. Marcano, J.G. Murillo, G.H. Lopez and J.A. Flores. 1997. The effect of using different levels of shrimp meal in broiler diets. Poultry Sci. 76:581-587.

Sarwono, B., 1996. Beternak Ayam Buras. Penebar Swadaya. Jakarta.

Sodiq, A. dan Z. Abidin. 2002. Penggemukan Domba. Angromedia Pustaka, Jakarta.

Susana, W, 1993 dalam Www.poultryindonesia.com diakses pada tanggal 04 Mei 2013

Wahju, J., 1998. Ilmu Nutrisi Unggas. Universitas Gadjah Mada Press. Yogyakarta.

Wahyuni, S dan R. Budiastuti. 1991. Respon Ayam Pedaging Terhadap Berbagai Tingkat Limbah Udang Olahan Dalam Ransum. Laporan Penelitian Fakultas Peternakan Universitas Padjadjaran. Bandung. 